\title{
COMPARATIVE STUDY OF ANTIOXIDANT AND ANTIMICROBIAL ACTIVITY OF ROOT, STEM AND LEAVES OF LEEA INDICA SPECIES
}

\author{
Aiza Harun 1,"Nor Erlena Asmira Ab Rahim ${ }^{1}$, Mohd Azfar Abd Jalil', Nurul 'Atiqah Muhammad \\ Rosdi $^{1}$, , Shaari Daud ${ }^{1}$, Siti Suhaila Harith ${ }^{1}$, Siti Zaiton Mat So'ad ${ }^{2}$, Norazian Mohd Hassan ${ }^{2}$ \\ ${ }^{1}$ Faculty of Applied Sciences, Universiti Teknologi MARA Pahang, Malaysia. \\ 26400 Bandar Tun Razak Jengka, Pahang, Malaysia. \\ ${ }^{2}$ Kulliyyah of Pharmacy, International Islamic University Malaysia \\ Bandar Indera Mahkota, Kuantan Pahang \\ *Corresponding author: aizaharun@ pahang.uitm.edu.my \\ Received: 18 Mei 2016 Revised: 9 Sept $2016 \quad$ Accepted:26 Sept 2016
}

\begin{abstract}
In this paper, we investigate the potency of Leea indica locally known as Memali plant from Tasik Chini, Pahang as a potent antioxidant and antimicrobial agent. Antibacterial activity of root, stem and leaf extracts of L. indica was evaluated against skin disease caused-microb Staphylococcus aureus and Staphylococcus epidermidis. Antioxidant activity was assessed by 2,2 diphenyl-1-picrylhydrazyl ( DPPH) thin layer chromatography (TLC) and dot blot assay method. The dichloromethane (DCM) extracts of all three parts displayed obvious antibacterial effect compared to other extracts and DCM extracts from leaves was the most effective in inhibiting the growth of $S$. epidermis with inhibition zone (IZ) of $18 \mathrm{~mm}$. The methanol extracts from stem scavenged DPPH radicals more effective than root and leaf extracts at a concentration as low as $0.19 \mathrm{mg} / \mathrm{ml}$. The antibacterial and antioxidant properties of leaves and stem might be attributed to the high content of terpenoid and phenolic. Thus, Memali appears to be a promising source of bioactive ingredients with antioxidant and antimicrobial activity.
\end{abstract}

Keywords: Leea indica, antimicrobial, antioxidant, phytochemicals, secondary metabolites

\begin{abstract}
Abstrak Kertas kerja ini meliputi penyelidikan ke atas potensi pokok Leea indica dari Tasik Chini, Pahang yang juga dipanggil Memali sebagai agen antioksidan dan antimikrob. Bahagian akar, batang dan daun dipilih untuk kajian aktiviti antibakteria dan antioksidan di mana ujian antibakteria menggunakan bakteria penyakit kulit seperti Staphylococcus aureus and Staphylococcus epidermidis. Ujian antioksidan menggunakan kaedah kromatografi lapisan nipis 2,2 diphenyl-1-picrylhydrazyl (DPPH) dan ujian dot blot. Didapati ekstrak dari diklorometana (DCM) menunjukkan aktiviti antimikrob yang lebih tinggi berbanding dengan ekstrak lain dan ekstrak dari daun mempunyai aktiviti yang paling tinggi dengan zon perencatan $18 \mathrm{~mm}$. Ujian antioksidan menunujukkan ekstrak metanol bahagian batang lebih efektif memerangkap radikal DPPH pada kepekatan serendah $0.19 \mathrm{mg} / \mathrm{ml}$. Sifat antioksidan dan antimikrob ini berkemungkinan akibat daripada adanya kandungan bahan seperti terpen dan fenolik yang tinggi. Maka pokok Memali dilihat sebagai punca asas bahan bioaktif yang bersifat antimikrob dan antioksidan.
\end{abstract}

Kata kunci: Leea indica, antimikrob, antioksidan, fitokimia, metabolit sekunder

\section{INTRODUCTION}

Recently, the need for treatment using traditional medicine is rising. The world started to rely back on herbs and health supplements due to the worldwide awareness to the importance of medicinal plants with nearly $80 \%$ of world populations
[1] depend on plant-based traditional herbal medicine as the source of their health care. Traditional medicine is described by the World Health Organization (WHO) as a health care system that applies on plant, animal and mineral-based medicines, manual method to cure, prevent and treat diseases. Antimicrobial activity is responsible for the treatment of allergy and 
skin diseases [2] while antioxidants such as ascorbic acid, phenolic compounds usually act by decreasing oxygen concentration, intercepting singlet oxygen as they oxidizes themselves instead. It helps body to keep protected against various type of oxidative damage that support such diseases like cancer, arthritis, diabetes and accelaration of the ageing process [3].

\section{Leea indica (Burm.f.) Meer} (Leeaceae) that comes from genus Leea is an abiding shrub woody plant growing up about 2-3 $\mathrm{m}$ in height, locally found and widely grown in tropical and subtropical countries such as India, Malaysia, Thailand and China. The other names for this species are Memali (Malay), Bandicoot Berry (English), Huo Tong Su (China) and Hastiplash (India). In Bangladesh and China, L. Indica has been used as traditional medicine for a past few decades [4,5] where it was traditionally used for treatment of diarrheoa, dysentry, colic, ulcers, skin diseases, vertigo, and headache. The leaves and roots were traditionally used to treat various illness such as diabetes, cardiac diseases, fever, headache, dizzinines, eczema, diarrhea and dysentry [4].

From previous studies on several Leea species, the stem and root extracts of $L$. rubra had been reported to exhibit antibacterial activities [6]. This study revealed that the ethyl acetate extracts of root and stem, ethanol and hexane extracts were active against gram-positive Bacillus subtillus and Staphyloccus aureus (IZ=9.0 \pm 0.5 to $17.5 \pm 0.5 \mathrm{~mm}$ ) but none against gram negative bacteria Escherichia coli and Pseudomonas aeruginosa. It had been reported that the antibacterial and antifungal activity of essential oil of L.indica flower was due to the major percentage of pthalates which are guiaiacol, anthole and $3 \mathrm{H}$ pyrazole that enhanced the effectiveness of essential oil of L.indica flower where, ethanol extract of $L$. Indica showed moderate activity with zone of inhibition of $6 \mathrm{~mm}$ against Gram-positive such as $S$. Aureus [7].

Methanol extracts from the whole plant of L.indica from Perak Malaysia showed high antioxidant and nitric acid inhibitory activities, whereby its root extract exhibited potential phosphodiestrase inhibitory activities that might be responsible for the strong antioxidant activity in L.indica extracts root [3]. The polar extract of L.indica leaves from Negeri Sembilan Malaysia was reported to exhibit a strong free radical scavenging activity which was due to high content of phenolic compounds [8].

\section{MATERIALS AND METHODS}

\section{Extracts Preparation}

The root, stem and leaves of $L$. indica which were collected from Tasik Chini Pahang, was firstly washed and cut into small pieces to aid the drying process. The plant pieces were then dried for 15 days at room temperature $\left(25 \pm 2^{\circ} \mathrm{C}\right)$, air-dried in the shade before ground into powder. The fine powder was stored for further extraction.

About $250 \mathrm{~g}$ of each part were soaked consecutively with petroleum ether (PE), dichloromethane (DCM), and methanol $(\mathrm{MeOH})$ and each soaking process was conducted three times. Each solvent extracts were then filtered, evaporated using rotary evaporator until dryness and placed in suitable vials prior to use. 


\section{Phytochemical Screening}

Alkaloids

$1 \mathrm{ml}$ methanol extract was added in a test tube together with hydrochloric acid in a steam bath. The mixture was filtered with Whatmann No. 1 filter paper. $1 \mathrm{ml}$ of the filtrate was tested with 6 drops of Mayer's Reagent (mixture of mercuric chloride and potassium iodide solution) and observe the formation of creamy white coloured precipitate. [9].

\section{$\underline{\text { Tannins }}$}

$1 \mathrm{ml}$ of methanol extract was added with a few drops of $10 \%$ lead acetate and the observed of precipitate indicated the presence of tannins.

\section{Saponins (Foam test)}

$1 \mathrm{ml}$ of methanol extract was shaken vigorously with $9 \mathrm{ml}$ of distilled water in a test tube. The process was conducted for a few minutes until the stable froth observed indicated the presence of saponins.

\section{$\underline{\text { Steroids and Terpenoids }}$}

Liebermann-Burchard test was performed to determine the presence of steroids and terpenoids. $2 \mathrm{ml}$ of extract was added with 1 $\mathrm{ml}$ of chloroform in a test tube. The mixture was added with a few drops of acetic anhydride and concentrated sulphuric acid along the side of the test tube. The presence of blue or green color indicated the presence of steroids and the appearance of red, brown colors indicated the presence of terpenoids.

\section{Cardiac Glycoside}

$1 \mathrm{ml}$ of methanol extract was added with a few drops of acetic acid. Then, the mixture was added with a few drops of ferric chloride and 3-4 drops of concentrated sulphuric acid. The appearance of blue green color showed the positive result for cardiac glycoside. $\underline{\text { Test for Flavanoids }}$

$3 \mathrm{ml}$ of methanol extract was added with concentrated hydrochloric acid. A magnesium ribbon was added into the mixture. The appearance of pink-red color indicated the presence of flavanoids.

\section{Fourier Transform Infra Red (FTIR) Analysis}

The methanol extract was placed on the sampling plate using dropper since the instrument used is Attenuated Total Reflectance (ATR) FTIR, the sample can be analyzed directly in liquid form. A background spectrum was obtained first before the sample was analyzed. Functional group was detected after undergoing process in ATR-FTIR.

\section{Disk Diffusion method}

In antibacterial assay, the standard inoculum of $S$. aureus and S. epidermis that were standardized at $0.5 \times 10^{6} \mathrm{CFU} / \mathrm{ml}$ by adjusting the optical density to 0.1 at 600 nm UV-VIS spectrophotometer were applied aseptically onto solidified nutrient agar (NA) using sterile cotton bud. The plate was then allowed to dry for 5 minutes. The impregnated disks of different extracts concentration which were previously serially diluted were placed aseptically on the agar surface. The activity was determined by the presence of clear zones of inhibition around the disks after incubation for overnight at $37^{\circ} \mathrm{C}$. The diameter of the clear zone of inhibition was measured in $\mathrm{mm}$ and it corresponded to the effectiveness of the extracts. Disks of ampicilin $(10 \mu \mathrm{g})$ were used as standard antibacterial or positive control and the solvent and empty discs were used as negative control. All determinations were conducted in triplicate [10]. 


\section{Thin layer Chromatography (TLC) Bioautography Assay}

The method was conducted after slight modification [11]. The innoculum concentration were measured and adjusted to the final concentrations of approximately $10^{6}$ cells $/ \mathrm{ml}$ for bacteria by mixing with sterile agar at $40^{\circ} \mathrm{C}$. About $20 \mathrm{~mL}$ of standardized molten inoculated agar was carefully overlaid on top of TLC which was previously developed. The bioautogram was left aside until the agar solidified. After the solidification of agar was completed, the plate was incubated at $37^{\circ} \mathrm{C}$ for 24 hours. After 24 hours incubation, a few iodin solids were placed to visualize any clear inhibition zone. The clear zone was detected as a clear zone against yellow background.

\section{Qualitative Antioxidant Screening}

The TLC plate was developed using suitable elution solvent system and left to dry. The plate then was sprayed with $0.6 \%$ (DPPH) in methanol and left aside in daylight within 30 minutes to 12 hours. The antioxidative compounds were observed as yellow spots against purple background on the TLC plate.

\section{Semi-Quantitative Antioxidant Activity: Dot-Blot Assay}

This method applied semi-quantitative technique where about $10 \mu \mathrm{L}$ of each extract was applied to $10 \times 10 \mathrm{~cm}$ TLC plate. The

Results from Table 1 indicated that all parts of $L$. indica contained saponin, steroid, terpenoid and tannin. Alkaloid can only be found in the leaves, flavonoid in the stem and root. The negative result of alkaloid screening test for stem and root and flavonoid in leaves might due to very little amount of alkaloid and flavonoid found in extracts were first diluted using serial dilution from $400 \mathrm{mg} / \mathrm{mL}$ to $6.25 \mathrm{mg} / \mathrm{mL}$. These different concentrations of extract were done in triplicate. The TLC plates were allowed to dry about 30 minutes. After dried, the TLC plates were brought to spray with $0.05 \%$ DPPH solution in methanol. The observation was obtained by observing the white spot around the extract applied. The white spot indicate the amount and nature of radical scavenger present in the sample [12].

\section{RESULTS AND DISCUSSION}

\section{Phytochemical Screening}

Table 1. Phytochemical screening of stem, leaves and root of L.indica

\begin{tabular}{lccc}
\hline $\begin{array}{l}\text { Phytochemical } \\
\text { Compound }\end{array}$ & Stem & Leaves & Root \\
\hline Alkaloids & - & + & - \\
Saponin & + & + & + \\
Steroids \& & + & + & + \\
Terpenoids & & & \\
Tannin & + & + & + \\
Cardiac & + & - & + \\
Glycoside & & & \\
Flavanoids & + & - & + \\
\hline
\end{tabular}

the extract and also the combination of all compounds in the methanol extract could possibly diminished the appearance of alkaloid and flavonoid in the extract. 


\section{FTIR Analysis}

The sample was directly analysed on the Spectrum 100 Spectrometer's crystal plate since we used Attenuated Total Reflectance (ATR) sampling. Generally all parts showed the presence of absorption peak of hydroxyl group $(\mathrm{OH})$ at 3500-3200 $\mathrm{cm}^{-1}$, carbonyl group $(\mathrm{C}=\mathrm{O})$ at $1716 \mathrm{~cm}^{-1}$, $\mathrm{C}-\mathrm{O}$ at $1235 \mathrm{~cm}^{-1}, \mathrm{C}=\mathrm{C}$ alkene at $1646 \mathrm{~cm}^{-1}$ and $\mathrm{C}-\mathrm{N}$ amine at $1014 \mathrm{~cm}^{-1}$. The results were comparable with those reported [13] where, the functional nature of terpenoids having oxygen was generally alcohol aldehyde, ketone or carboxylic groups. The presence of $\mathrm{O}-\mathrm{H}$ bond in the compound can be determined by the formation of acetates with acid anhydrides and benzoyate with 3,5-dinitrobenzyl chloride. Other compounds that contain functional nature of alcohol group and carbonyl group are cardiac glycosides, tannins and flavonoids. They mostly contain alcohol group and $\mathrm{C}=\mathrm{O}$ bond in compound. Most of these secondary metabolites exhibit antioxidant properties. At $1014.10 \mathrm{~cm}^{-1}$, there were indication of amino groups which corresponded to $\mathrm{C}-\mathrm{N}$ bond. However, there was no $\mathrm{N}-\mathrm{H}$ stretch identified in the spectrum. Thus, tertiary amine may be determined. Alkaloids are compounds that have nitro based group in their structure. They have basic elements of carbon, hydrogen and nitrogen with most of them also contain oxygen. 


\section{In-Vitro Antimicrobial Activity Assay}

Table 2 shows the results of antibacterial activity against S.aureus and S.epidermidis for stem, root and leaves of $L$. indica species.

Table 2. Antibacterial Activity of stem, root and leaves of $L$. indica species.

\begin{tabular}{|c|c|c|c|c|c|c|c|}
\hline \multirow[b]{3}{*}{ Extract } & \multirow[b]{3}{*}{$\begin{array}{l}\text { concentraction } \\
(\mathrm{mg} / \mathrm{ml})\end{array}$} & \multicolumn{2}{|c|}{ STEM } & \multicolumn{2}{|c|}{ LEAVES } & \multicolumn{2}{|c|}{ ROOT } \\
\hline & & \multicolumn{2}{|c|}{$\begin{array}{l}\text { zone of } \\
\text { inhibition }(\mathrm{mm})\end{array}$} & \multirow{2}{*}{$\begin{array}{r}\begin{array}{l}\text { zone } \\
(\mathrm{mm})\end{array} \\
\mathrm{SA}\end{array}$} & \multirow{2}{*}{$\begin{array}{c}\text { inhibition } \\
\text { SE }\end{array}$} & \multicolumn{2}{|c|}{$\begin{array}{l}\text { zone of inhibition } \\
(\mathrm{mm})\end{array}$} \\
\hline & & SA & $\mathrm{SE}$ & & & SA & $\mathrm{SE}$ \\
\hline Petroleum & 50 & 6.0 & 8.0 & 6.0 & 6.0 & - & - \\
\hline \multirow[t]{3}{*}{ Eter } & 100 & 6.0 & 8.0 & 6.3 & 6.0 & - & - \\
\hline & 200 & 6.0 & 9.6 & 6.0 & 6.3 & - & - \\
\hline & 400 & - & - & 6.0 & 6.0 & - & - \\
\hline \multirow[t]{4}{*}{ DCM } & 50 & 6.3 & 7.0 & 6.7 & 6.0 & 8.7 & 7.3 \\
\hline & 100 & 6.6 & 6.0 & 7.3 & 6.0 & 8.2 & 9.0 \\
\hline & 200 & 7.6 & 9.6 & 7.8 & 18.0 & 6.0 & 9.3 \\
\hline & 400 & 8.0 & 12.3 & 7.3 & 6.0 & 6.3 & 9.7 \\
\hline \multirow[t]{4}{*}{ Methanol } & 50 & 6.0 & 6.0 & 6.7 & 6.0 & 8.3 & 7.3 \\
\hline & 100 & 6.0 & 6.0 & 6.7 & 6.0 & 8.3 & 6.0 \\
\hline & 200 & 6.6 & 6.0 & 7.3 & 17.3 & 7.8 & 6.0 \\
\hline & 400 & 6.6 & 6.6 & 7.0 & 6.0 & 7.8 & 6.0 \\
\hline Ampicilin & $10 \mathrm{ug} / \mathrm{ml}$ & 19 & 35 & 19 & 3.5 & 19 & 35 \\
\hline
\end{tabular}

SA: $S$ aureus; SE: S. epidermidis ; DCM : dichloromethane; IZ 0-6 mm: no activity; 7-10 mm: weak inhibition; 11-15 mm: moderate inhibition; more than $16 \mathrm{~mm}$ : strongly inhibited 
Results shown in Table 2, indicate that for stem extracts of L.indica, DCM extract exhibited the highest antibacterial activity with inhibition zone of $12.3 \mathrm{~mm}$ against S.epidermis at a concentration of 400 $\mathrm{mg} / \mathrm{ml}$ compared to petroleum ether extract and methanol extract. However DCM extract was moderately inhibited the growth of $S$. aureus at $400 \mathrm{mg} / \mathrm{ml}$ but weakly inhibited the growth of bacteria at $50 \mathrm{mg} / \mathrm{ml}$ with inhibition zone ranging from $6.3 \mathrm{~mm}$ to $8.0 \mathrm{~mm}$. Petroleum ether extract and methanol extracts seemed to demonstrate no antibacterial activity against both bacteria with no inhibiton zone appearing around the disks. However petroleum ether extract weakly inhibited the growth of S.epidermidis with $9.6 \mathrm{~mm}$ zone diameter at $200 \mathrm{mg} / \mathrm{ml}$. Thus, for stem extract, DCM extract was found to be the most active extract. The results also indicated that the antibacterial activity is in a concentration dependent manner against both bacteria. Figure 1 shows the antibacterial activity of DCM extract from the stem of $L$. indica.

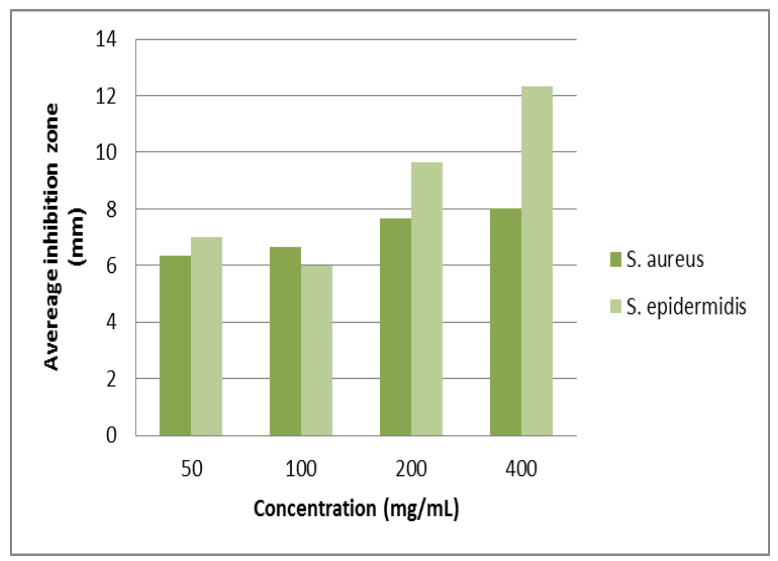

Figure 1. Antibacterial activity of DCM extract from the stem of $L$. indica

For leaf extracts of $L$. indica, DCM extract and methanol extract were strongly inhibited the growth of S.epidermidis with inhibition zone of $18.0 \mathrm{~mm}$ and $17.3 \mathrm{~mm}$ respectively at concentration $200 \mathrm{mg} / \mathrm{ml}$. However, both extracts were weakly inhibited the growth of $S$. aureus with the range of zone of inhibition of $6.7 \mathrm{~mm}-7.8$ $\mathrm{mm}$. Petroleum ether extract seemed to show no antibacterial activity against both bacteria since no inhibition zone can be seen around the disks. Thus, for the leaf extract, DCM extract was the most active extract compared to other extracts and $S$. epidermidis was more susceptible compared to $S$. aureus. This means DCM extract of leaf was the most effective extract against both bacteria. As a conclusion, the most effective concentration is $200 \mathrm{mg} / \mathrm{ml}$ for all types of extract of L.indica leaves.

According to Nascimento et al. [14], the lower concentration extracts were probably effective due to the factor of toxic effect where, a higher concentration of extract will increase the toxicity and eventually interfered the effectiveness of the extract. Therefore, this could be one of the reasons why methanol extract of $L$ indica leaves was strongly inhibited the growth of bacteria at concentration $200 \mathrm{mg} / \mathrm{ml}$ compared at $400 \mathrm{mg} / \mathrm{ml}$. Figure 2 shows the antibacterial activity of DCM extract from the leaves of L. indica

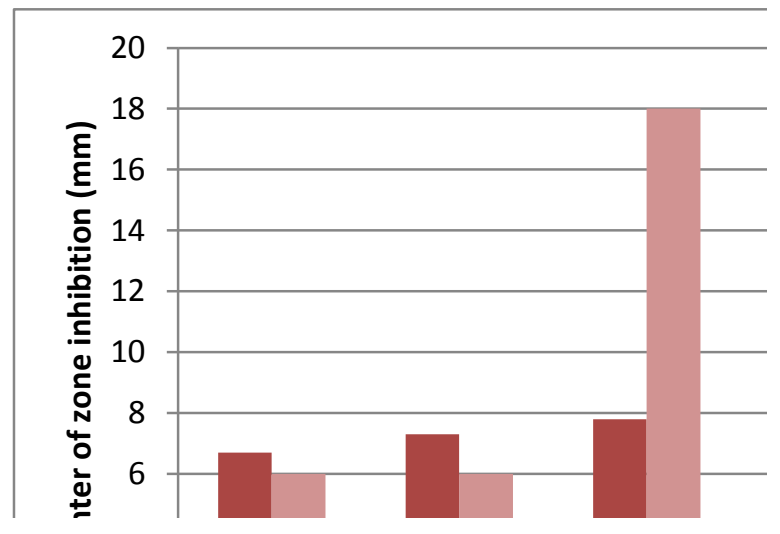

Figure 2. Antibacterial activity of DCM extract from the leaves of L. indica 
For the root extracts of L. indica, DCM extract exhibited antibacterial activity against S.epidermidis in a concentration dependent manner where the highest IZ was $9.7 \mathrm{~mm}$ at $400 \mathrm{mg} / \mathrm{ml}$. The extract almost showed moderate activity at this concentration compared to methanol extract. On the other hand, the antibacterial activity was weaker against S.aureus with the range of IZ of $8.3-7.8 \mathrm{~mm}$ and the most polar extract methanol seemed to exhibit no antibacterial activity against S.epidermidis. It has been reported that antibacterial activity was enhanced at lower concentration and it was probably caused by the presence of synergic effect in a lower concentration of extract. It means the antibacterial activity was more effective at lower concentration. The synergic effect of higher concentration extract was not the main cause that contributed to the antibacterial activity. The extracts were able to penetrate the thick cell walls through general diffusion at lower concentration as compared to higher concentration extract [14]. Thus, our results were compatible with those previously reported result. Since terpenoid and flavanoid were found in DCM extract and methanol extract, both secondary metabolites were most probably responsible for the effectiveness of the DCM extracts of stem, leaves and root of $L$. indica. Figure 3 shows the antibacterial activity of DCM extract from the leaves of L. indica

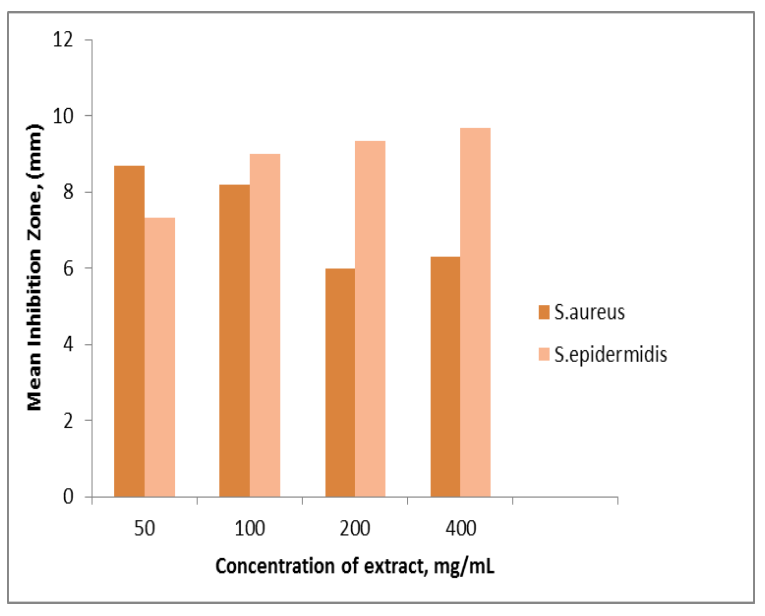

Figure 3. Antibacterial activity of DCM extract from the root of $L$. indica 


\section{Agar Overlay Thin Layer Chromatography (TLC) Bioautography Assay}

This experiment was conducted to evaluate the effectiveness of each separate component in inhibiting the growth of bacteria solely with respect to clear inhibition zone.

Table 3. Thin Layer Chromatography (TLC) Agar Overlay Bioautography of Stem, Root and Leaves of $L$. indica species.

\begin{tabular}{|c|c|c|c|c|c|c|}
\hline & \multicolumn{2}{|c|}{ STEM } & \multicolumn{2}{|c|}{ LEAVES } & \multicolumn{2}{|c|}{ ROOT } \\
\hline \multirow[t]{2}{*}{ Extract } & \multicolumn{2}{|c|}{$\begin{array}{l}\text { zone of } \\
\text { inhibition }(\mathrm{mm})\end{array}$} & \multicolumn{2}{|c|}{$\begin{array}{l}\text { zone of inhibition } \\
(\mathrm{mm})\end{array}$} & \multicolumn{2}{|c|}{$\begin{array}{l}\text { zone of } \\
\text { inhibition }(\mathrm{mm})\end{array}$} \\
\hline & SA & $\mathrm{SE}$ & SA & $\mathrm{SE}$ & SA & $\mathrm{SE}$ \\
\hline Eter & $\begin{array}{c}\text { no } \\
\text { zone }\end{array}$ & $\begin{array}{c}\text { no } \\
\text { zone }\end{array}$ & $\begin{array}{c}\text { no } \\
\text { zone }\end{array}$ & no zone & $\begin{array}{c}\text { no } \\
\text { zone }\end{array}$ & $\begin{array}{c}\text { no } \\
\text { zone }\end{array}$ \\
\hline DCM & $\begin{array}{l}\text { zone at } \\
\mathrm{R}_{\mathrm{f}} 0.25\end{array}$ & $\begin{array}{c}\text { zone } \\
\text { at } R_{\mathrm{f}} \\
0.25\end{array}$ & $\begin{array}{c}\text { no } \\
\text { zone }\end{array}$ & no zone & $\begin{array}{c}\text { zone at } \\
\mathrm{R}_{\mathrm{f}} \\
0.11 \\
\text { and } \\
0.26\end{array}$ & $\begin{array}{c}0.11 \\
0.15 \\
0.23 \\
0.26 \\
0.36 \\
0.43\end{array}$ \\
\hline Methanol & $\begin{array}{c}\text { no } \\
\text { zone }\end{array}$ & $\begin{array}{c}\text { no } \\
\text { zone }\end{array}$ & $\begin{array}{c}\text { no } \\
\text { zone }\end{array}$ & no zone & $\begin{array}{c}\text { no } \\
\text { zone }\end{array}$ & $\begin{array}{l}\text { zone at } \\
\mathrm{R}_{\mathrm{f}} 0.89\end{array}$ \\
\hline
\end{tabular}

PE: Petroleum ether; DCM: dichloromethane; SA: S.aureus; SE: S.epidermidis 
Table 3 indicated the results of TLC agar overlay bioautography of stem, leaves and root of L. indica. For the stem, the results established the disk diffusion semiquantitative results, where a zone of inhibition appeared at $R_{f}$ 0.25. For $P E$ extract of stem, there was still a weaker antibacterial activity observed against $S$. epidermidis in disk diffusion assay, but the zones of inhibition was totally unseen in TLC agar overlay bioautography. This was due to the synergistic effect of the antibacterial agents in the extract. Synergistic effect can only be recognized when mixture of compounds give greater effect than that of individual bioactive compounds [15].

For DCM extract of stem, the inhibition zone was seen individually only at $\mathrm{R}_{\mathrm{f}}=0.25$ against both bacteria on bioautogram. The active component at this $\mathrm{R}_{\mathrm{f}}$ value could probably belongs to plant protein such as lectins and polypeptides that can form yellow-white spot after spraying with Dragendorff's reagent and possessed antibacterial activity [16]. However, there were no inhibition zones which can be observed from isolated compounds on bioautogram when using methanol extract. It means isolated compounds from methanol extract were not effective enough to inhibit the growth of bacteria singly whereas when all compounds came into contact they tend to inhibit the growth of bacteria well enough.

For DCM extract of the root, the inhibition zone on bioautogram against $S$. aureus can be individually seen at $\mathrm{R}_{\mathrm{f}}=0.11$ and 0.26, however the bioautogram of PE and methanol extract did not reveal any inhibition zones for each of the separated components. This trend also similar for PE extract against $S$ epidermidis. The inhibition zone on bioautogram of DCM extract can be observed at range of $R_{\mathrm{f}} 0.07$ 0.43 against $S$. epidermidis and it was found that saponin, terpenoid and cardiac glycosides were the bioactive compounds that are responsible for the appearance of zone on bioautogram. Only a single inhibition zone against $S$. epidermidis can be observed on the bioautogram of methanol extract of root at $R_{f}=0.89$ and it resulted from the presence of phenolic compound. Thus the results established the effectiveness of DCM extract of the root against $S$. epidermidis through disc diffusion method. However no inhibition zone was observed at any $R_{f}$ values of isolated compound of methanol extract. 


\section{Qualitative Analysis of Antioxidant Activity}

Table 4 shows the results of TLC antioxidant screening test for stem, root and leaves of $L$. indica when sprayed wth $0.6 \% \mathrm{DPPH}$.

Table 4. TLC antioxidant screening test for stem, root and leaves of $L$. indica.

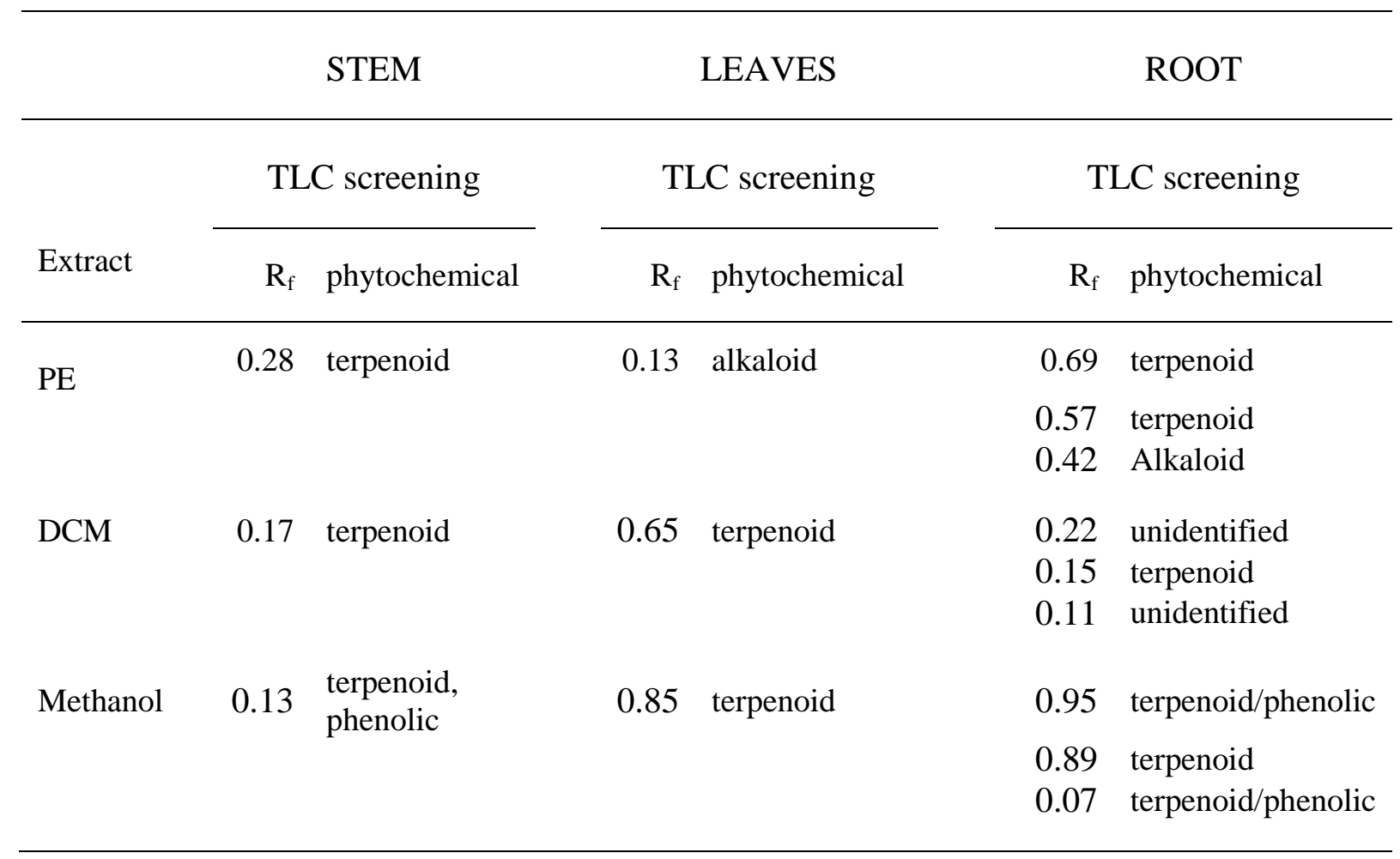

Table 4 shows the results of TLC of stem, root and leaves that revealed antioxidant properties at different $\mathrm{R}_{\mathrm{f}}$ values when sprayed with $0.6 \%$ DPPH. The yellow spot that was observed against purple background give the indication of the presence of antioxidative compounds. The compounds that were responsible for the antioxidative activity were mainly terpenoid, phenolic and alkaloid. For the stem, terpenoid and phenolic were responsible for its antioxidant properties. Terpenoid and alkaloid were also the antioxidative compounds in leaves and for the root, terpenoid, phenolic and alkaloid were the main source of the antioxidant behavior.

However, the rate of alkaloid scavenged 0.6\% DPPH was quite slower and only occurred 12 hours after spraying process. This result can be deduced as a weak antioxidant activity for alkaloid in L.indica extract but very strong for terpenoids and phenolic compounds found in $\mathrm{MeOH}$ extract. Previous findings by Srinivasan et al. [7] suggested that polyphenolic of gallic acid compound was as an antioxidant in L.indica in which it was consistent with our finding and most 
probably the polyphenolic of gallic acid was also found in the extracts.

It was also reported that the compounds contained different individual characteristic whereby some of the them have strong radical scavenging activity, thus able to reduce DPPH radical rapidly, while some have low radical scavenging activity, consequently lengthen the time for reaction to complete [17]. Furthermore, the antioxidant compounds in the extracts would not operate in the same manner and possibly more effective if different free radicals were used. According to Dawidowicz et al. [18], the solvent used to dilute the DPPH and extracts can somewhat influence the reaction kinetic by taking part in reaction between DPPH and antioxidant compounds.

The DPPH free radical scavenging activity is based on the ability of 2,2diphenyl-2-picryl-hydrazyl, a stable free radical to be decolourised in the presence of antioxidants [19]. The DPPH radical contains an odd electron which is responsible for the absorbance at 515-517 $\mathrm{nm}$ and visible deep purple colour. The DPPH is decolourised when it accepts an electron donated by an antioxidant compound. Thus, it can be quantitatively measured from the changes in absorbance [20].

\section{Semi-quantitative Analysis of Antioxidant Activity: DPPH Staining Dot Blot Assay}

Semi-quantitative DPPH staining was conducted using dot blot assay method. This method prescribed on which concentration prepared showed highest intensity of white spot capacity on the TLC plate. It was an eye-detected semiquantitatively rapid screening method and only based on the inhibition of the accumulation of oxidized products [21] and the white colour represented the nature of radical scavenger presented in selected concentration of extract [12].

For the root of $L$. indica, it was observed that the methanol extract has highest intensity of white spot compared to DCM extract. The white spot can still be observed at concentration until $6.25 \mathrm{mg} / \mathrm{mL}$. While for DCM extract, the intensity of white spot decreased from $400 \mathrm{mg} / \mathrm{mL}$ to $6.25 \mathrm{mg} / \mathrm{mL}$. It has been investigated that polyphenolic compounds such as tannins and flavanoids from methanol extract were the main role in stabilizing lipid oxidation and somewhat related to antioxidant activity [22]. The difference of the intensity of white spot might also be due to the synergic effect of different compounds selective in certain concentration [23] .Thus, we can conclude that the reduced intensity of white spot from $400 \mathrm{mg} / \mathrm{mL}$ to $6.25 \mathrm{mg} / \mathrm{mL}$ was due to synergic effect.

The dot blot assay results for stem and leaves revealed that the methanol extract having the same trend as the methanol extract in the root where, the intensity of the white spot remained the same as the concentration of the extract reduced from $400 \mathrm{mg} / \mathrm{mL}$ until $0.19 \mathrm{mg} / \mathrm{mL}$ (in stem) and from $400 \mathrm{mg} / \mathrm{mL}$ until $12.5 \mathrm{mg} / \mathrm{mL}$ (in leaves). The strong antioxidant activities detected in methanol extract in stem and leaves of $L$. indica could be due to the presence of typical phenolic compounds such as flavonoids and phenolic acids [24]. Such activity of phenolic compounds was mainly due to its redox properties that allow them to act as reducing agent, hydrogen donating agent and singlet oxygen quenching $[8,25]$. Figure 4 shows the dot blot assay results using DCM and methanol extract of $L$. indica leaves and stem 


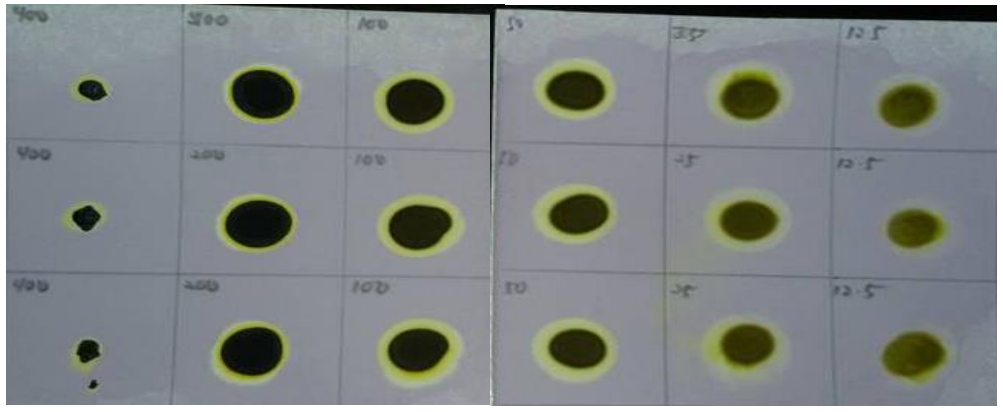

(A)

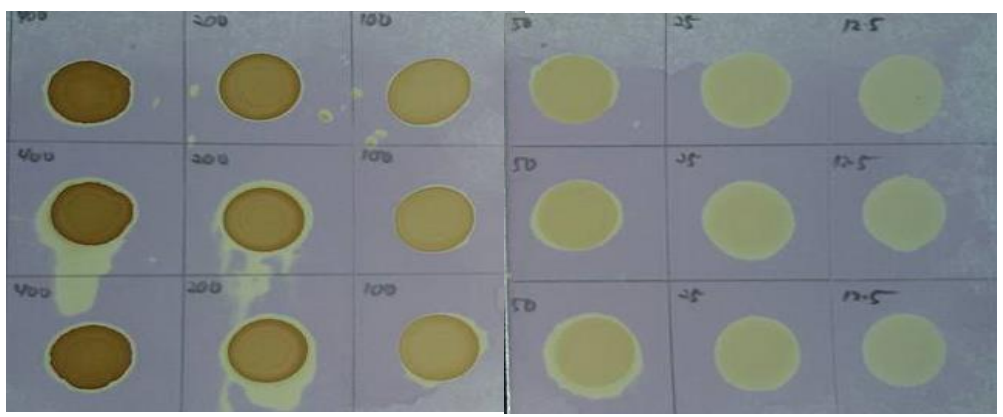

(B)

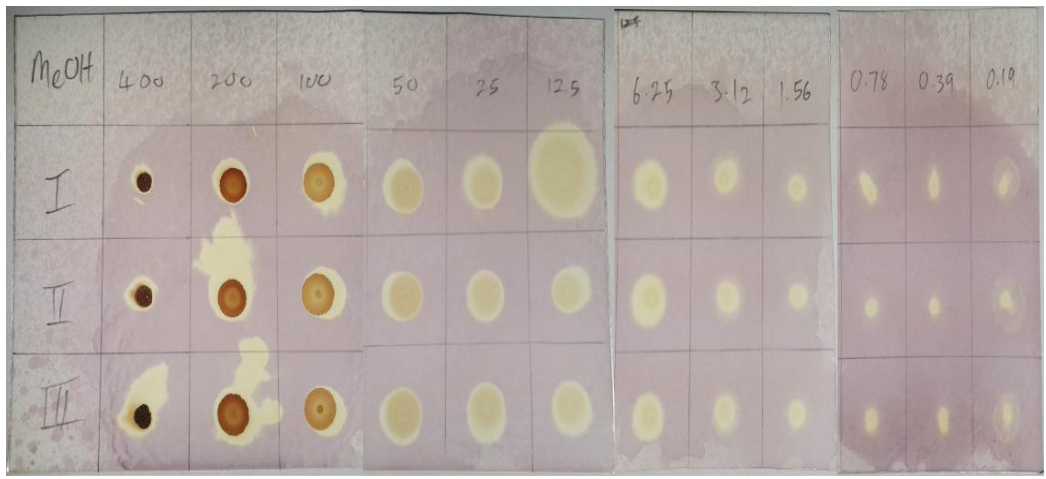

(C)

Figure 4. Dot blot assay results for DCM and methanol extract of $L$. indica leaves and stem. Concentration decreases from left to right. (A): DCM leave extract; (B): Methanol leave extract; (C): Methanol stem extract

\section{CONCLUSION}

L. indica generally exhibited both antioxidant and antibacterial properties. Among three types of extracts, the DCM extracts exhibited stronger antibacterial properties for all the three plant parts of $L$. indica. The DCM extract of leaves possessed the largest inhibition zone of 18 $\mathrm{mm}$ against $S$. epidermis and thus $S$. epidermis was more susceptible and the DCM extract from the leaves is the most active extract. Methanol extracts possessed stronger antioxidant properties with terpenoid and phenolic compound which act as antioxidative compounds. However, further investigation need to be carried out in detail to determine the chemical structure 
of the antibacterial and antioxidative compounds.

\section{ACKNOWLEDGEMENT}

We would like to express our gratitude to all Chemistry and Biology Laboratory Staf of Universiti Teknologi Mara Pahang Malaysia for THEIR SUPPORT until the completion of our investigation.

\section{REFERENCES}

1. Savirathmma, N., Rao, M. L., and Suhrulatha, D. (2011). Screening of Medicinal Plants for Secondary Metabolites. Middle-East Journal of Scientific Research, 8(3)(579-584).

2. Antolovich, M., Prenzler, P. D., Patsalides, E., McDonald, S., and Robards, K. (2001). Methods for Testing Antioxidant Activity. doi: 10.1039/b009171p.

3. Saha, K., Lajis, N. H., Israf, D. A., and A.S. Hamzah, S. K., S. Khamis, A. Syahida. (2004). Evalluation of antioxidant and Nitric Oxide Inhibitory Activities of Selected Malaysian Medicinal Plants. Journal of Ethnopharmacology, 92, 263-267. doi: doi:10.1016/j.jep.2004.03.007

4. Bais, S. (2013). A Phytopharmacological Review on an Important Medicinal Plant: Leea Indica.

5. Rahman, M. A., Imran, T. B., and Islam, S. (2012). Antioxidative Antimicrobial and Cytotoxic effects of the Phenolics of Leea indica Leaf extract. doi: 10.1016/j.sjbs.2012.11.007
6. Kadchumsang, S., Sirisa-ard, P., Sookkhee, S., Eakanunkul, S., and Chansakaow, S. (2014). Antibacterial and Antioxidant Activities of Various Fraction of Leea rubra (Leeaceae). Journal of Natural Sciences Research, Vol. 4(11). doi: 10.1155/2011/293060

7. Srinivasan, G. V., Sharanappa, P., Leela, N. K., Sadashiva, C. T., and Vijayan, K. K. (2009). Chemical Composition and Antimicrobial Activity of the Essential Oil of Leeaindica (Burm.f) Merr. Flowers. Natural Product Radiance, Volume 8, 488-493.

8. Reddy, N. S., Navanesan, S., Sinniah, S. K., Wahab, N. A., and Sim, K. S. (2012). Phenolic content, antioxidant Effect and Cytotoxic Activity of Leea indica Leaves. BMC Complementary and Alternative Medicine, 12, 128

9. Pavitra, P.S., Sreevidya, N., and Verma, R.S., (2009). Antibacterial and antioxidant activity of methanol extract of Evolvus nummularius. Indian J. Pharmacol, 41 (5), 233236.

10. Mutai, C., Bii, C., Vagias, C., Abatis, D., and Roussis, V. (2009). Antimicrobial activity of Acacia mellifera extracts and lupane triterpenes. Journal of Ethnopharmacology, 123(1), 143$148 . \quad$ doi: http://dx.doi.org/10.1016/j.jep.2009. $\underline{02.007}$

11. Norazian M.H., (2009). Bioassay-guided isolation of natural products workshop: Bioautographic screening and isolation of antimicrobial and 
antioxidant compounds. Natural Medical Products Centre.

12. Dong-Jiann, H., Hsien-Jung, C., ChunDer, L., and Yaw-Huei, L. (2005). Antioxidant and Antiproliferative Activities of Water Spinach (Ipomea aquatica Forsk) Constituents. Botanical Bulletin of Academia Sinica, 46, 99-106.

13. Bano, S. (2007). Terpenoids. Chemistry of Natural Product.

14. Nascimento, G. G. F., Locatelli, J., Freitas, P. C., \& Silva, G. L. (2000). Antibacterial Activity of Plant Extracts and Phytochemicals on Antibiotic Resistant Bacteria. Brazilian Journal of Microbiology, 31, 247-256.

15. Palaniappan, K., and Holley, R. A. (2010). Use of natural antimicrobials to increase antibiotic susceptibility of drug resistant bacteria. International Journal of Food Microbiology, 140, 164-168.

doi:

10.1016/j.ijfoodmicro.2010.04.001

16. Qadir, U., Paul, V. I., and Ganesh, P. (2015). Preliminary phytochemical screening and in vitro antibacterial activity of Anamirta cocculus (Linn.) seeds. Journal of King Saud University - Science, 27(2), 97-104. doi: 10.1016/j.jksus.2014.04.004

17. Chang, W. C., Sei, C. K., Soon, S. H., Bong, K. C., Hye, J. A., Min, Y. L., . . Soo, K. K. (2002). Antioxidant activity and free radical scavenging capacity between Korean medicinal plants and flavonoids by assayguided comparison. Plant Science, 163, 1161-1168.
18. Dawidowicz, A. L., Wianowska, D., and Olszowy, M. (2012). On practical problems in estimation of antioxidant activity of compounds by DPPH method (Problems in estimation of antioxidant activity). Food Chemistry, 131, 1037- 1043. doi: 10.1016/j.foodchem.2011.09.067

19. Kumarasamy, Y., Byres, M., Cox, P. J., Jaspars, M., Nahar, L., Sarker, S. D., (2007). Screening seeds of some Scottish plants for free-radical scavenging activity. Phytotherapy Research. 2, (7), 615-621 pp.

20. Subhan, N., Alam, M.A., Ahmed, F., Awal, M.A., Nahar, L., and Sarker, S.D., (2008). In vitro antioxidant property of the extract of Excoecariaagallocha

(Euphorbiaceae). DARU. 16 (3), 149-154.

21. Wang, J., Yue, Y.-D., Tang, F., and Sun, J. (2012). TLC Screening for Antioxidant Activity of Extracts frm Fifteen Bamboo Species and Identification od Antioxidant Flavone Glycosides from Leaves of Bambusa textilis McClure. Molecules, 17, 12297-12311. doi: 10.3390/molecules 171012297.

22. Yen, G. C., and Chen, H. Y. (1995). Antioxidant Activity of Various Tea Extracts in Relation to Their Antimutagenicity. Journal of Agricultural Food Chemistry, 43(1), 27-32. doi: JF940387.

23. Hatano, T., Edamatsu, R., Hiramitsu, M., Mori, A., Fujita, Y., Yasuhara, T., and Okuda, T. (1989). Effects of the 
Interaction of Tannins with Coexisting Substances : Effects of Tannins and Related Polyphenols on Superoxide Anion Radical and on 1,1-Dipenyl-2picrylhydrazyl

Radical. Chemistry of Pharmacy Bulletin, 37(8), 2016-2021.

24. Wojdylo, A., Oszmianski, J., and Czemerys, R. (2007). Antioxidant activity and phenolic compounds in 32 selected herbs. Food Chemistry, 105(3), 940-949. doi: 10.1016/j.foodchem.2007.04.038 doi: 10.1016/j.fitote.2003.07.013

25. Evan (n.d). Alkaloids. Pharmacopoeial and Related Drugs of Biological Origin, 26(5), 353-415. 